\title{
Conjunctival vessel abnormalities in sickle cell diseases: the influence of age and genotype
}

\author{
W. C. A. Siqueira', M. S. Figueiredo², A. A. V. Cruz', \\ F. F. Costa ${ }^{2}$ and M. A. Zago ${ }^{2}$ \\ Departments of Ophthalmology ${ }^{1}$ and Clinical Medicine ${ }^{2}$, School of Medicine, \\ 14.049 - Ribeirão Preto, Brazil
}

\begin{abstract}
Conjunctival vessels were examined with a slit-lamp and the abnormalities were graded in $77 \mathrm{pa}-$ tients with sickle cell diseases, including 48 with sickle cell anaemia, 17 with sickle cell $\beta^{\circ}$-thalassaemia and 12 with $\mathrm{HbS} / \mathrm{HbC}$ disease. The study demonstrated the occurrence of similar conjunctival vessel abnormalities for the three sickle cell diseases which are, however, more severe in HbS homozygotes than in the two other genotypes. An increase of the severity of the vascular abnormalities with the increase of patient age was also observed for HbS homozygotes. The data suggest that the conjunctival lesions accumulate and increase in severity in a similar fashion as other tissue damages observed in sickle cell diseases.
\end{abstract}

Key words: sickle cell anemia - haemoglobin S - conjunctiva - microvasculature.

Almost every organ may be affected by the abnormal rheological properties of the sickle erythrocytes, and the eyes are no exception (Serjeant 1985). Different types of retinal lesions may occur, which may cause transient or permanent visual loss (Goodman et al. 1957; Lieb et al. 1959; Serjeant 1985; Roy et al. 1987; Bonanomi et al. 1988). The conjunctival vessels are also affected by the disease and a specific conjunctival vascular pattern has been described in sickle disease (Goodman et al. 1957; Lieb et al. 1959; Geeraets \& Guerry 1960; Munro \& Walker 1960; Fink et al. 1961, 1964; Paton 1961, 1962; Comer \& Fred 1964; Serjeant et al. 1972; Nagpal et al. 1977). Although of little func- tional significance, these vascular abnormalities are of considerable interest since they allow the direct observation of the effects of sickling and other blood alterations upon small vessels (Knisely et al. 1947; Fink et al. 1964).

The diagnostic value of the conjunctival sign has been confirmed in several studies (Fink et al. 1961, 1964; Paton 1961, 1962), especially for HbS homozygotes, but at least two problems remain unresolved. First, the severity of the conjunctival lesions associated with the different genotypes of sickle cell diseases has not been established. By pooling data from six different studies (Geeraets \& Guerry 1960; Paton 1961, 1962; Comer \& Fred 1964; Serjeant et al. 1972; Nagpal et al. 1977) we note that only $58 \%$ of 64 patients with SC disease had conjunctival changes as compared with $95 \%$ of $248 \mathrm{HbS}$ homozygotes, thus suggesting that patients with SC diseases are less severely affected. Nevertheless, no consistent pattern can be deduced from the only $6 \mathrm{HbS} / \beta$-thalassaemia patients thus far reported in two different studies (Paton 1961, 1962).

The abnormalities seem less prominent and more easily reversible in younger patients (Fink et al. 1961, 1962; Paton 1962; Serjeant et al. 1972). However, a direct relationship between age and the severity of the conjunctival vessel changes has not been clearly established.

We report the results of a study of the conjunc- 
tiva of Brazilian patients with sickle cell diseases, which demonstrate that the changes are less severe in $\mathrm{HbS} / \beta^{\circ}$-thalamassaemia than in $\mathrm{HbS}$ homozygotes and that the abnormalities accumulate with increasing patient age.

\section{Material and Methods}

The investigations were performed on 77 patients with sickle cell diseases: 48 with sickle cell anemia (SS), 17 with sickle cell $\beta^{\circ}$-thalamassaemia $\left(\mathrm{S} / \beta^{\circ}\right.$ thal) and 12 with $\mathrm{HbS} / \mathrm{HbC}$ disease (SC). The patients ranged in age from 3 to 47 years. For comparative purposes, 14 controls were also studied. Diagnosis was established in each case by clinical, laboratory and family studies. Hemoglobin concentrations were measured with a TOA Hemoglobinometer and $\mathrm{HbF}$ was quantitated by alkali denaturation. $\mathrm{HbA}_{2}$, measured by elution after electrophoresis, was in the normal range in all SS patients, and was elevated in all $S / \beta^{\circ}$-thal patients. $\mathrm{HbS}$ was identified by electrophoresis on cellulose acetate at alkaline $\mathrm{pH}$ and on agar-citrate, and by low solubility in concentrated phosphate buffer. The globin chain synthesis of peripheral blood reticulocytes (Costa \& Zago 1986) was unbalanced for all 17 patients with sickle cell $S / \beta^{\circ}$-thal. All patients regularly attended the Hemoglobinopathy Outpatient Clinic and were not in crisis when evaluated nor had they been transfused in the previous 4 months.

The conjunctival observations were made independently by two ophthalmologists who did not know the history or diagnosis of the patient. The examinations were performed with a Zeiss slitlamp with $12.5 \times$ oculars and magnifications of
$10 \times$ or $16 \times$. Each of the observers examined one eye, in order to avoid the effect of warming due to prolonged exposure of the conjunctiva to the slitlamp heat. The examiner identified the most affected area of the bulbar conjunctiva, and classified the abnormalities into five grades of severity (from 0 to 4) according to the criteria of Serjeant et al. (1972): grade 0, normal conjunctival vasculature; grade 1, occasional abnormal long linear dilatations of vessels connected to vascular network; grade 2, numerous linear dilatations, some apparently unconnected from background vascular network; grade 3, short linear dilatations in association with short, dark, truncated, and curved vessel segments frequently apparently unconnected to background vascular network; grade 4, multiple short, dark, truncated vessel segments apparently unconnected to background vascular network. The two examiners agreed on the classification of $77 \%$ of cases $(57 / 74$ patients) who were evaluated by both of them. The difference was of one grade for $\mathbf{1 6}$ and two grades for only one of the remaining 17 cases. For the 17 cases where there was a difference in classification, the higher grade was utilized.

\section{Results}

The results are summarized in Tables 1 and 2.

One SS patient and about one-fourth of the $S / \beta^{\circ}$-thal and SC patients had no abnormalities (grade 0 ) of conjunctival vessels. The three controls who were not grade 0 had minimal (grade 1) alterations (in two cases the two observers had disagreed and assigned grades 0 and 1 ). For purposes of statistical analysis, the first three grades (0-2).

Table 1.

Conjunctival vessel abnormalities in patients with sickle cell diseases and normal controls.

\begin{tabular}{c|c|c|c|c}
\hline Grade & SS & S/ $\beta^{\circ}$-thal & SC & Controls \\
\hline 0 & $1(2.1 \%)$ & $4(23.5 \%)$ & $3(25.0 \%)$ & $11(78.6 \%)$ \\
1 & $2(4.2 \%)$ & $3(17.6 \%)$ & $4(33.3 \%)$ & $3(21.4 \%)$ \\
2 & $1(2.1 \%)$ & $2(11.8 \%)$ & $1(8.3 \%)$ & 0 \\
3 & $10(20.8 \%)$ & $6(35.3 \%)$ & $4(33.3 \%)$ & 0 \\
4 & $34(70.8 \%)$ & $2(11.8 \%)$ & 0 & 0 \\
\hline Total & 48 & 17 & 12 & 14 \\
\hline
\end{tabular}


Table 2.

Age distribution (median and range in years) of patients with sickle cell diseases according to the grade of conjunctival vessel changes.

\begin{tabular}{c|r|c|c|c|c|c}
\hline \multirow{2}{*}{ Grades } & \multicolumn{2}{|c|}{ SS } & \multicolumn{2}{c|}{ S/ $\beta^{\circ}$-thal } & \multicolumn{2}{c}{ SC } \\
\cline { 2 - 7 } & Median & Range & Median & Range & Median & Range \\
\hline \multirow{2}{*}{$0-3$} & $4^{*}$ & $3-6$ & 9 & $4-22$ & 16 & $5-47$ \\
$3-4$ & $14^{*}$ & $3-34$ & 13 & $6-20$ & 22 & $14-37$ \\
\hline
\end{tabular}

* Significantly different, $\chi^{2}=4.01 ; P<0.05$.

and the last two grades (3-4) were combined. The percentage of cases assigned grades 3 or 4 was $0 \%$ for controls, $33 \%(4 / 12)$ for $S C, 47 \%(8 / 17)$ for $S / \beta^{\circ}$ thal and $92 \%(44 / 48)$ for SS homozygotes. The distributions were significantly different for the three sickle cell genotypes $\left(\chi^{2}=23.6, P<0.005\right)$, but the difference between the $S / \beta^{\circ}$-thal and $S C$ genotypes was not significant.

The age distribution of the three patient groups according to the severity of the lesions were also different (Table 2). Thus, all of the 39 SS patients of more than 7 years had grades 3-4, whereas 11 of the $24 \mathrm{~S} / \beta^{\circ}$-thal and SC patients aged more than 7 years had grades 3-4. The median age of patients with grades 3-4 is higher than those of patients with grades 0-2 for the three genotypes, and the difference was statistically significant for the SS patients (median test, $\chi^{2}=4.01, P<0.05$ ). The increasing severity of the abnormalities with the increase of age for the group of SS homozygotes is represented graphically in Fig. 1.

\section{Discussion}

The present study demonstrates that abnormalities of the conjunctival vessels are qualitatively similar for the three different sickle cell diseases: $\mathrm{HbS}$ homozygotes, $\mathrm{S} / \beta^{\circ}$-thal and $\mathrm{HbS} / \mathrm{HbC}$ disease. The lesions are, however, more severe in $\mathrm{HbS}$ homozygotes than in the two other genotypes. $\mathrm{Al}-$ though a difference between $\mathrm{HbS} / \mathrm{HbC}$ and $\mathrm{S} / \beta^{\circ}$ thal was not demonstrable, presumably because of the number of patients, our data suggest that $S / \beta^{\circ}$ thal patients may be more severely affected than those with $\mathrm{HbS} / \mathrm{HbC}$ disease.

An increase of the severity of the vascular abnormalities with the increase of patient age was dem- onstrated for SS homozygotes. This is in agreement with isolated observations reporting more benign lesions which are more easily reversible in younger patients (Fink et al. 1961, 1964; Paton 1962; Serjeant et al. 1972). All of our SS patients of more than 7 years of age (39/39) had grade 3-4 conjunctival lesions whereas in the 3-6 year range only 5/9 patients had grades 3-4.

A significant correlation between severity of conjunctival vessel changes and counts of irreversibly sickled cells (ISC) has been reported for sickle cell diseases (Serjeant et al. 1972; Nagpal et al. 1977), but this parallelism is rather complex and it

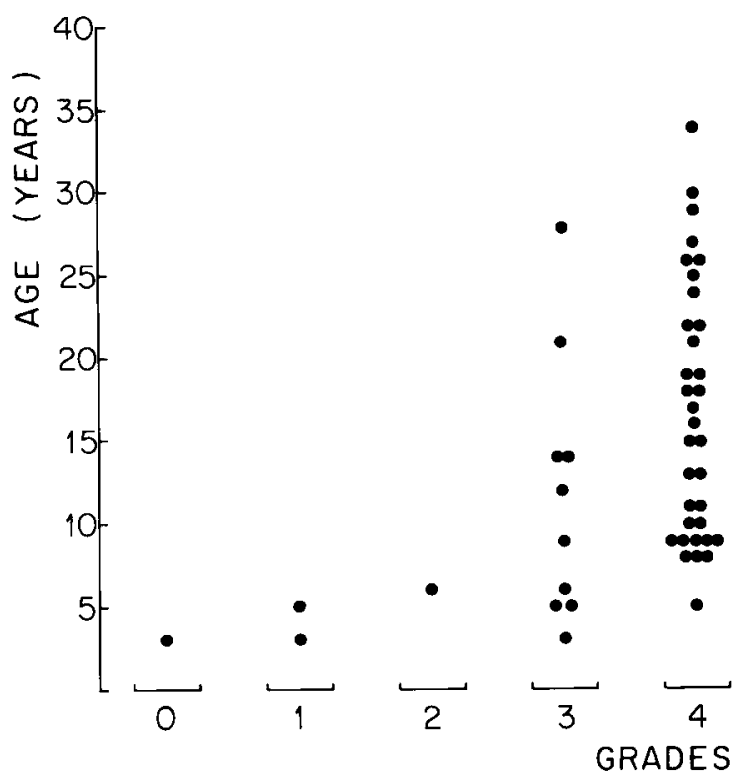

Fig. 1.

Grade of conjunctival vessel lesion for $\mathrm{HbS}$ homozygotes classified according to the criteria of Serjeant et al. (1972) as compared with patient age. 
should not be taken as an indication of a causal relationship. Actually, many determinants of a low ISC are also determinants of a more benign clinical course and of fewer vasoocclusive episodes. Once the faster decrease of $\mathrm{HbF}$ concentration of the neonatal period has stabilized between 1-3 years of age, the severity of the disease will be determined mainly be a combination of genetic factors (such as $\mathrm{HbF}$ levels after stabilization, the mean corpuscular haemoglobin and the presence of $\mathrm{HbC}, \mathrm{HbD}$ or thalassaemia) (Serjeant 1985) and this will determine the frequency of vasoocclusive phenomena and the rate of chronic tissue damage. Although the postnatal decrease of $\mathrm{HbF}$ levels is slower in sickle cell diseases than in normals, most of these patients have already reached almost stable adult $\mathrm{HbF}$ levels and all had developed a full clinical picture at the time that they were evaluated. Thus, the lower grade of lesions for the patients at the lower age range does not seem to depend on a direct protective effect of high $\mathrm{HbF}$ levels at the moment of evaluation. The data suggest that the conjunctival lesions accumulate and increase in severity in a similar fashion as other tissue damages caused by vasoocclusion (Serjeant 1985), such as proliferative retinopathy, splenic hypofunction and atrophy (Zago \& Bottura 1983), and leg ulcers.

Thus, similar vascular changes, including those of the conjunctivae, are observed in the three most common sickle cell diseases, but they occur and accumulate earlier in $\mathrm{HbS}$ homozygotes and later or with less severity in $S / \beta^{\circ}$-thal or $\mathrm{HbS} / \mathrm{HbC}$ disease.

\section{Acknowledgment}

This work was supported by CNPq, Brazil.

\section{References}

Bonanoni M T B, Cunha S L \& Araujo J T (1988): Fundoscopic alterations in SS and SC hemoglobinopathies: study of a Brazilian population. Ophthalmologica (Basel) 197: 26-33.

Comer P B \& Fred H L (1964): Diagnosis of sickle-cell disease by ophthalmoscopic inspection of conjunctiva. $N$ Engl J Med 271: 544-545.
Costa F F \& Zago M A (1986): Bone marrow and peripheral blood globin chain synthesis in sickle cell $\beta^{\circ}$ thalassaemia. J Med Genet 23: 252-255.

Fink A I, Funahashi T, Robinson M \& Watson R J (1961): Conjunctival blood flow in sickle-cell disease: preliminary report. Arch Ophthal 66: 824-829.

Fink A I, Funahashi T, Robinson M, Watson R J \& Felix M (1964): Conjunctival blood flow in sickle-cell disease: responses to local stimuli. Trans Am Acad Ophthal Otolaryng 68: 301-315.

Geeraets WJ \& Guerry D (1960): Clinical observations on conjunctival capillaries with special reference to sickle cell disease: preliminary report. Southern Med J 53: 949-952.

Goodman G, von Sallmann L \& Holand M G (1957): Ocular manifestations of sickle cell disease. Arch Ophthal 58: 655-682.

Knisely M N, Bloch E M, Eliot T S \& Warner L (1947): Sludged blood. Science 106: 431-440.

Lieb W A, Geereats W J \& Guerry D III (1959): Sickle cell disease. Acta Ophthalmol Suppl (Copenh) 58: 1-45.

Munro S \& Walker C (1960): Ocular complications in sickle cell haemoglobin C disease. Brit J Ophthal 44: 1-24.

Nagpal K C, Asdourian G K, Goldbaum M H, Raichand M \& Goldberg M F (1977): The conjunctival sickling sign, hemoglobin S, and irreversibly sickled erythrocytes. Arch Ophthalmol 95: 808-811.

Paton D (1961): The conjunctival sign of sickle-cell disease. Arch Ophthalmol 66: 90-94.

Paton D (1962): The conjunctival sign of sickle-cell disease: further observations. Arch Ophthalmol 68: 627632.

Roy M S, Rodgers G, Gunkel R, Noguchi C \& Schechter A (1987): Color vision defects in sickle cell anemia. Arch Ophthalmol 105: 1676-1678.

Serjeant G R, Serjeant B E \& Condom P I (1972): The conjunctival sign in sickle cell anemia. JAMA 219: 1428-1431.

Serjeant G R (1985): Sickle cell disease, Oxford University Press, Oxford.

Zago M A \& Bottura C (1983): Splenic function in sickle cell diseases. Clin Sci 65: 297-302.

Received on December 19th, 1989.

Author's address:

Marco A. Zago, M.D.,

Department of Clinical Medicine,

School of Medicine,

14.049, Ribeirão Preto,

Brazil. 